\title{
Determination of Radiography Requirement with Physical Examination in Elbow Trauma
}

\section{Dirsek Travmasında Fizik Muayene Bulguları ile Radyografi Gerekliliğinin Belirlenmesi}

\author{
Mücahit Günaydın', @Vildan Özer², @Yunus Karaca², Ali Aygün3, OÖzgur Tatlı2, \\ (D)Aş̧egül Cansu'4, Abdülkadir Gündüz²
}

\author{
'Giresun University Faculty of Medicine, Department of Emergency Medicine, Giresun, Turkey \\ ${ }^{2}$ Karadeniz Technical University, Faculty of Medicine Department of Emergency Medicine, Trabzon, Turkey \\ ${ }^{3}$ Ordu University, Faculty of Medicine Department of Emergency Medicine, Ordu, Turkey \\ ${ }^{4}$ Karadeniz Technical University, Faculty of Medicine Department of Radiology, Trabzon, Turkey
}

\begin{abstract}
Objective: The purpose of this study was to estimate the presence of fracture and to determine radiography requirements through results obtained by evaluating the physical examination findings in elbow injury.

Material and Method: This was a single center prospective study. All patients were evaluated in terms of trauma mechanism, inspection findings, presence of pain at palpation, pain with active movement, circulatory examination and loss of sensation. Sensitivity, specificity, positive and negative predictive value (NPV) were determined for each sign and each examination finding.

Results: The study was performed with 47 patients. Fracture was determined in 10 patients (21.2\%). Presence of pain at the elbow extansion, forearm supination (FS), medial epicondyle (ME) palpation and forearm pronation tests exhibited high sensitivity $(100 \%, 100 \%, 90 \%$, and $80 \%$, respectively) and high NPV (100\%, $95 \%, 96.4 \%$, and $91 \%$, respectively) for elbow fracture. These four tests produced significant $p$ values $(0.088,0.012,0.001$, and 0.079 , respectively) in elbow fractures. Combining the pain at FS and ME palpation tests exhibited $90 \%$ sensitivity, and $96.7 \%$ NPV.

Conclusions: Positivity on any one of the four tests employed increases the probability of fracture and is sufficient for elbow radiography to be recommended in patients presenting due to elbow injury. However, radiography may not be required if combined FS and ME palpation test findings are negative in this patients.
\end{abstract}

Keywords: Elbow fracture, physical examination, radiography requirement, emergency medicine
Öz

Amaç: Bu çalışmada dirsek travmasında fizik muayene ve dirsek eklem fonksiyonlarını ölçen bazı testlerin yapılması ve bu veriler ışığında hangi hastalarda kırık olabileceğinin değerlendirilmesi amaçlanmaktadır.

Gereç ve Yöntem: Bu prospektif klinik çalışmada, tüm hastalar travmanın mekanizması, inspeksiyon bulguları, palpasyon ile ağı varlığı, aktif hareket ile ağı varlığı, dolaşım muayenesi ve duyu kaybı açısından değerlendirildi. Tüm semptom ve bulguların sensitivite, spesivite, pozitif prediktif değer ve negatif prediktif değerleri (NPD) istatistiksel olarak belirlendi.

Bulgular: Çalışma 47 hasta ile yürütüldü. Toplamda 10 hastada kırık saptandı (\%21,2). Dirsek ekstansiyonu, ön kol supinasyonu (ÖS), medial epikondil (ME) palpasyonu ve ön kol pronasyon testleri ile ağrı varlığının dirsek kırığı için sensitivitesi yüksekti (sırasıyla, \%100, \%100, \%90 ve \%80). Dirsek kırığı için bu 4 testin p değeri anlamlı olarak tespit edildi (sırasıyla, 0,088,0,012,0,001, and 0,079). ÖS ve ME palpasyon testlerinin birlikte değerlendirilmesinin sensitivitesi \%90 ve NPD'si $\% 96,7$ olarak tespit edildi.

Sonuç: Kullanılan bu dört testten herhangi birinin pozitif olması kırık olasılığını arttıır ve dirsek yaralanması nedeniyle başvuran hastalarda dirsek radyografisinin önerilmesi için yeterlidir. Ancak bu hastalarda birlikte değerlendirilen ÖS ve ME palpasyon testi bulguları negatif ise radyografi gerekmeyebilir

Anahtar Kelimeler: Dirsek kırığı, fizik muayene, radyografi gerekliliği, acil servis

Corresponding (illetişim): Mucahit Gunaydin, Giresun University, Faculty of Medicine, Department of Emergency Medicine 28100 Giresun, Turkey E-mail (E-posta): mgunaydin@hotmail.com 


\section{INTRODUCTION}

Elbow traumas constitute 2-3\% of emergency department presentations. ${ }^{[1,2]}$ The most feared event following acute elbow trauma is complex fracture accompanied by severe neurovascular injury. Cases of missed fracture may also occur under some conditions, such as a simple and undisplaced fracture. ${ }^{[3]}$ The diagnosis of an existing fracture is important since disability may be observed following elbow injuries. However, there is still no specific agreed procedure for the identification of elbow traumas. ${ }^{[4-9]}$

The ability to determine fractures on direct x-rays in some patients with normal physical examination obliges physicians to request large numbers of $x$-ray tests. This prolongs emergency department stays, and leads to patients being unnecessarily exposed to radiation, and to increased treatment costs. Results showing that $x$-ray is not necessary in every case of wrist trauma in recent studies revealed a need for procedures to be followed in elbow trauma. ${ }^{[5-11]}$ Some studies intended to identify those patients for whom $x$-ray should be requested have reported that extension tests at physical examination may be sufficient, ${ }^{[9]}$ while the most recent studies have shown that the elbow extension test and fracture point tenderness test cannot by themselves exclude elbow injury. ${ }^{[12]}$

The purpose of this study was to perform various tests measuring elbow joint functions in patients presenting to the emergency department with acute elbow trauma and to identify those patients in whom fractures may be present in the light of the data obtained. The ultimate purpose of all these evaluations was to identify a procedure in the light of clinical examination for determining the need for $x$-ray requests in patients presenting to hospital with wrist trauma.

\section{MATERIAL AND METHOD}

\section{Study Design and Setting}

This prospective, single-center study was conducted in an university hospital teaching emergency medicine assistant physicians (50.000 ED visits annually). The study was performed between December 2015 and August 2016 following receipt of ethical committee approval (No. 2013/8).

Patients aged over 18, with elbow trauma and presenting to the emergency department within the first $72 \mathrm{~h}$, and consenting to participate were included in the study. Patients with multiple trauma, clouded consciousness, known neuromuscular disease, trauma in the contralateral elbow or forearm, with open fracture or with another distracting injury were excluded from the study. All patients were examined, and an examination form specially designed for this study was completed for all patients. All patients were evaluated in terms of trauma mechanism, inspection findings, presence of pain at palpation medial epicondyle (ME), lateral epicondyle (LE), olecranon, and radial head $(\mathrm{RH})$, ulnar and median nerve sensation tests, radialbrachial and ulnar artery pulse examination, pain during elbow flexion (EF) and elbow extension (EE), and pain during forearm pronation (FP) and forearm supination (FS).

\section{Methods and Measurements}

The emergency department physicians taking part in the study were instructed concerning the standard elbow examination techniques used in it. The examination results of the patients assessed using these techniques were recorded onto a form produced for the study. The physicians examined patients in terms of deformity findings in the affected region, and presence of ecchymosis and swelling, and the data obtained were recorded on the study form. Each patient was evaluated for tenderness when the medial ME, LE, olecranon, and $\mathrm{RH}$ were touched. The radial, ulnar, and brachial artery pulses were palpated, and circulation examination was performed. Median and ulnar nerve sensation examinations were performed, and the presence of sensory loss was noted. Patients were also evaluated for presence of pain with active movements (pain at $\mathrm{EE}$ and $\mathrm{EF}$, and pain at FP and FS), and the results were recorded on the study form.

Once the physical examinations were complete, and irrespective of the physical examination findings, all patients were sent to the radiology unit for two-sided radiography (anteroposterior and lateral). The recordings were made with a digital $x$-ray device (Konica Minolta Aero Dr X70). The radiography results were reported by an experienced radiologist blinded to the study findings. Patients with suspected fracture but in whom this could not be confirmed with radiography underwent computerized joint tomography, the results of which were reported by the same radiologist. Computerized joint tomography was performed using a Siemens Sensation 16 Slice device. The presence and location of fracture were recorded for patients with fractures diagnoses using radiography and tomography.

Radiographic examination of elbow bone traumas represented the primary end point for establishing the validity of the proposed criteria in order to determine their predictive value in producing a clinical decision-making tool for the management of such patients. The predictive value of each individual criterion was first calculated separately. Combinations of findings exhibiting the highest predictive values for fracture were then evaluated together.

\section{Statistical Analysis}

Statistical analysis was performed on SPSS (Chicago, IL) 21.0 software. Descriptive characteristics (side affected, mechanism of trauma, and dominant hand) were expressed as numbers and percentages. Sensitivity, specificity, and positive and negative predictive values (NPV) for all symptoms and examination findings were expressed as percentages. Incidences of symptoms between fracture and non-fracture groups were analyzed using the Pearson $\mathrm{X} 2$ and Fisher exact tests. P values < 0.05 were regarded as statistically significant.

\section{RESULTS}

Eighty-seven patients presenting to our emergency departments during the study period were included. Twentytwo patients with multiple traumas, two with open fractures, 
six unwilling to take part, and 10 with missing records were excluded from the study, which was finally performed with 47 patients. Men represented $78.7 \%(n=37)$ of the patients in the study and women $21.3 \%(n=10)$. Trauma mechanisms involved falling onto the elbow in $68.1 \%$ of cases $(n=32)$, sports injuries in $10.6 \%(n=5)$, vehicular accidents in $2.1 \%(n=1)$, and other injuries in $19.1 \%(n=9)$. Right hand dominance was present in the great majority of patients (97.9\%), and the right elbow was the most commonly affected region (59.6\%). Fracture was determined in 10 patients (21.2\%). The pathological findings of these 10 subjects with fractures are shown in Table 1.

The data, and predictive values, of patients with or without fracture determined at physical examination, point palpation and active movements are shown in Table 2. Among the clinical findings, pain occurring with EE exhibited the highest sensitivity values, with sensitivity and NPV of $100 \%$. The second highest sensitivity values, at $90 \%$, were pain occurring with FS and
ME palpation and NPV of $95.4 \%$ and $96.4 \%$, respectively. Pain occurring with FP exhibited sensitivity of $80 \%$ and NPV of $91 \%$. These four tests with significant $p$ values $(0.088,0.012,0.001$, 0.079 , respectively) in elbow fracture. We also evaluated the sensitivity in determining the presence of fracture by combining the pain test with the $\mathrm{FS}$ and ME palpation, these tests with the highest $p$ value $(<0.001)$. The combination of these two tests exhibited $90 \%$ sensitivity, $81 \%$ specificity, and NPV $96.7 \%$.

Table 1. Details of patients with fractures on elbow radiographs

Radiological diagnosis Number of patients $\quad$ Percentage (\%)

Radial head fracture

Medial epicondyle fracture

Lateral epicondyle fracture

Supracondylar fracture

Radial head dislocation

Proximal ulna fracture

Total

$\begin{array}{cc}3 & 30 \\ 2 & 20 \\ 2 & 20 \\ 1 & 10 \\ 1 & 10 \\ 1 & 10 \\ 10 & 100\end{array}$

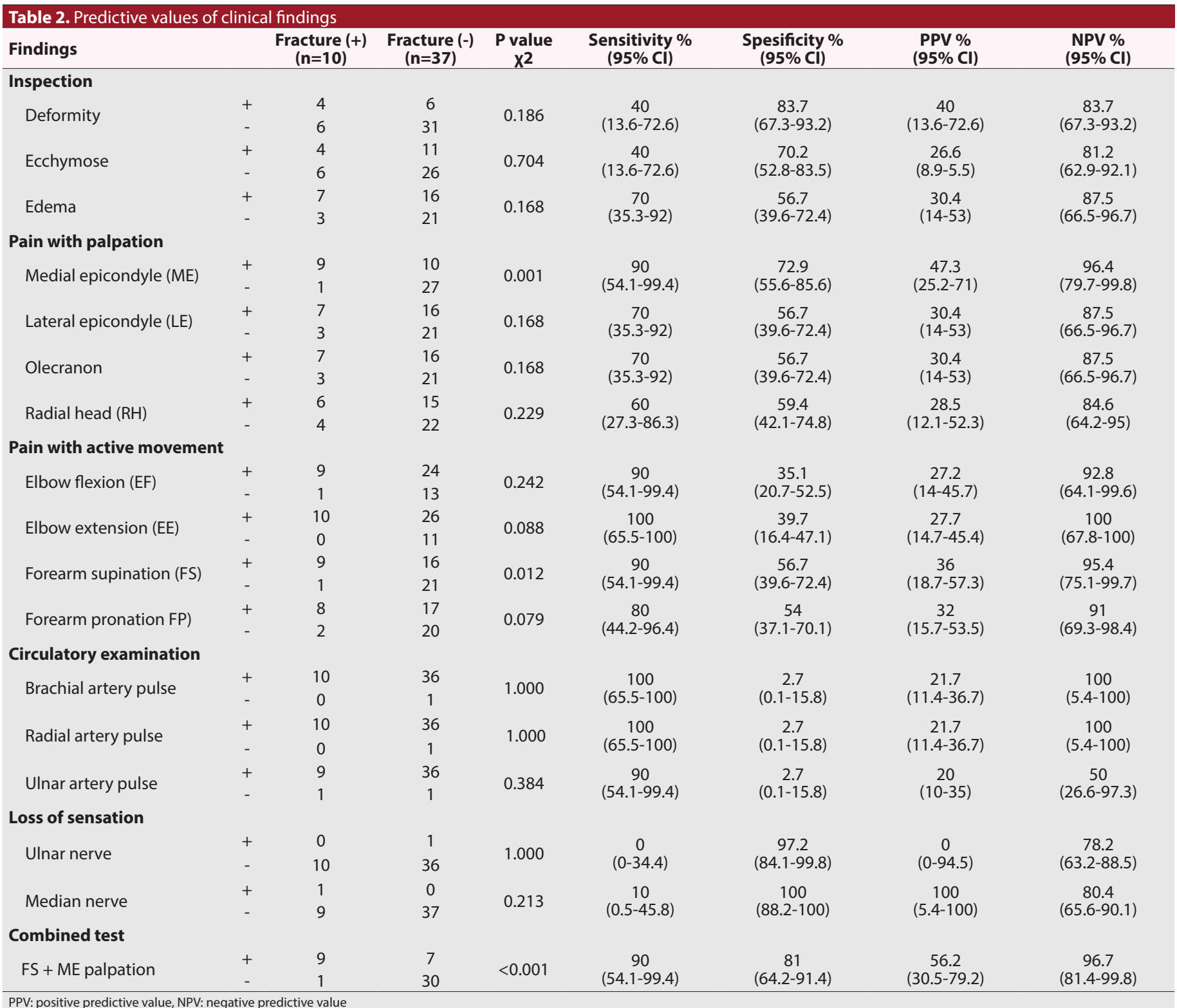




\section{DISCUSSION}

We determined that pain at EE was 100\% sensitive for diagnosis of fracture. The occurrence of pain with the FS and palpation of the ME in patients with trauma was $90 \%$ sensitive in diagnosing fracture, while pain at FP was $80 \%$ sensitive in the presence of pain. These four tests, being capable of rapid, simple and practical application, emerged as physical examination findings with high sensitivity and significant $p$ values in determining the presence of fracture in elbow injuries. When we evaluated FS and palpation of the ME of the humerus, the two tests with the highest $p$ values, this combination exhibited $90 \%$ sensitivity in identifying the presence of fracture.

Due to a lack of specific rules concerning which patients should be sent for radiography in elbow trauma, one of the most common reasons for presentation to the emergency department, a number of studies have been performed on this subject. ${ }^{[1,2]}$ One study of 145 patients by Hawksworth et al. ${ }^{[9]}$ described the EE test as an important marker in showing the presence of injury, with sensitivity of $90.7 \%$ and specificity of $69.5 \%$. They also reported that if the patient is able to achieve full extension, the probability of significant injury is only $9.3 \%$. In a similar study of 114 patients, Docherty et al. ${ }^{[8]}$ described full extension as a practical marker in the emergency department, with $97 \%$ sensitivity and $69 \%$ specificity, and reported that this test reduced radiography requirements in patients presenting with elbow trauma by $50 \%$. All of the patients with determined fractures in our study were unable to achieve full EE, and the EE test exhibited $100 \%$ sensitivity and $39.5 \%$ specificity in identifying the presence of fracture. Our study confirms those previous studies, revealing a high probability of injury in patients with positive EE tests, and the need to refer these for radiography.

Appelboam et al. ${ }^{[4]}$ reported a NPV for the EE test of $98.4 \%$, with a negative likelihood ratio of 0.03 . Based on these values, they concluded that EE had high specificity and NPV, that the test was practicable in the emergency department, and that radiography requirements for patients presenting with elbow trauma would be reduced by a quarter. They also concluded that the likelihood of fracture appearing at x-ray on patients unable to achieve full extension was approximately $50 \%$. We obtained similar results in the present study, with EE exhibiting $100 \%$ sensitivity and NPV in determining the presence of fracture.

Lennon et al. ${ }^{[2]}$ concluded that a patient able to perform the same range of elbow movements in both elbows, affected and unaffected by trauma, could safely be discharged, that there was no need for patients able to perform normal extension, flexion and supination to be sent for x-ray, but that there was a risk, albeit a low one, of inability to identify pathology at $x$-ray in adult patients even if physical examination is normal. Darracq et al. ${ }^{[13]}$ expressed a different opinion, reporting that equal ranges of elbow movement in both arms, affected and unaffected by trauma, considerably reduced the probability of determining fracture in these patients. In our study, EE, FS and FP tests and presence of pain at palpation of the ME had high sensitivity and specificity, whereas the EF test was not statistically significant in determining the presence of fracture. A combination of FS and ME palpation tests was statistically significant $(p=<0.001)$ and exhibited $90 \%$ sensitivity.

Arundel et al. ${ }^{[14]}$ reported that a combination of the ability to perform full extension, absence of pain or tenderness with application of pressure to either the $\mathrm{RH}$, the olecranon or the $M E$, and the absence of contusion-ecchymosis was $100 \%$ sensitive and $24 \%$ specific in determining fracture in elbow trauma. In our study, the presence of pain at palpation of the $\mathrm{RH}$ and olecranon was not statistically significant in determining the presence of fracture ( $p=0.229,0.168$, respectively), and only pain at pressure on the medial epicondyle was significant $(p=0001)$, with sensitivity of $90 \%$ and specificity of $72.9 \%$. The EE test in the present study was $100 \%$ specific. The statistical significance of FS and ME palpation tests was higher in our study, and due to the high sensitivity, specificity and NPV values of a combination of these two tests in identifying the presence of fracture, we think that this combination is suitable for determining the presence of fracture in the emergency department. Kim et al. ${ }^{[12]}$ also reported that the use of the EE test alone or the single point tenderness test alone could not exclude elbow injuries. In our study, too, use of the EE test alone was not appropriate, while a combination of FS and ME palpation tests was more suitable.

\section{Limitations}

The principal limitation of this study is the low patient number. The main reason for this low number is that only isolated elbow traumas were included and injuries accompanying multitrauma were excluded. A second important limitation is that range of elbow movement was not included in the physical examination findings. According to Darracq et al.'s study ${ }^{[13]}$, the addition of these parameters with high sensitivity in determining elbow traumas to physical examination findings, and to the combination of results obtained will result in more significant results in determining the presence of fracture.

\section{CONCLUSIONS}

Positivity on any one of the four tests (EE, FS, ME palpation, and FP tests) employed increases the probability of fracture and is sufficient for elbow radiography to be recommended in patients presenting due to elbow injury. However, radiography may not be required if combined $\mathrm{FS}$ and $\mathrm{ME}$ palpation test findings are negative in this patients, and this can significantly reduce the numbers of non-essential radiographs performed.

\section{ETHICAL DECLARATIONS}

Ethics Committee Approval: For this research; Karadeniz Technical University Faculty of Medicine Ethic Council approval was obtained (Date: 29,08,2013 number: 2013/35). 
Informed Consent: All patients signed the free and informed consent form.

Referee Evaluation Process: Externally peer-reviewed.

Conflict of Interest Statement: The authors have no conflicts of interest to declare.

Financial Disclosure: The authors declared that this study has received no financial support.

Author Contributions: All of the authors declare that they have all participated in the design, execution, and analysis of the paper, and that they have approved the final version.

Acknowledgements: The authors thank Suha Turkmen, Mehmet Emre Baki, Oguz Eroglu and Alper Timurkaynak for coordination at the beginning of the study

\section{REFERENCES}

1. Freed HA, Shields NN. Most frequently overlooked radiographically apparent fractures in a teaching hospital emergency department. Ann Emerg Med. 1984;13(10):900-4.

2. Lennon RI, Riyat MS, Hilliam R, Anathkrishnan G, Alderson G. Can a normal range of elbow movement predict a normal elbow $\mathrm{x}$ ray? Emerg Med $\mathrm{J}$. 2007;24(2):86-8.

3. Nalbantoğlu U, Gereli A. Fracture dislocations of the elbow: overview and classification. TOTBID Derg 2014; 12:51-56.

4. Appelboam A, Reuben AD, Benger JR, et al. Elbow extension test to rule out elbow fracture: multicentre, prospective validation and observational study of diagnostic accuracy in adults and children. BMJ. 2008;337:a2428.

5. Stiell IG, Greenberg GH, McKnight RD, et al. Decision rules for the use of radiography in acute ankle injuries. Refinement and prospective validation. JAMA. 1993;269(9):1127-32.

6. Stiell IG, Wells GA, McDowell I, et al. Use of radiography in acute knee injuries: need for clinical decision rules. Acad Emerg Med 1995;2:966-73.

7. Perry JJ, Stiell IG. Impact of clinical decision rules on clinical care of traumatic injuries to the foot and ankle, knee, cervical spine, and head. Injury 2006;37:1157-65.

8. Docherty MA, Schwab RA, Ma OJ. Can elbow extension be used as a test of clinically significant injury? South Med J 2002;95:539-41.

9. Hawksworth CR, Freeland P. Inability to fully extend the injured elbow: an indicator of significant injury. Arch Emerg Med 1991;8:253-6

10. Turkmen S, Cansu A, Karaca $Y$, et al. Determination of radiography requirement in wrist trauma. Am J Emerg Med. 2015;33(9):1269-72.

11. Karaca Y, Turkmen S, Cansu A, et al. A study to develop clinical decision rules for the use of radiography in wrist trauma: Karadeniz wrist rules. Am J Emerg Med. 2016;34(11):2074-8.

12. Jie KE, van Dam LF, Verhagen TF, Hammacher ER. Extension test and ossal point tenderness cannot accurately exclude significant injury in acute elbow trauma. Ann Emerg Med. 2014;64(1):74-8.

13. Darracq MA, Vinson DR, Panacek EA. Preservation of active range of motion after acute elbow trauma predicts absence of elbow fracture. Am J Emerg Med. 2008;26(7):779-82

14. Arundel D, Williams P, Townend W. Deriving the East Riding Elbow Rule (ER2): a maximally sensitive decision tool for elbow injury. Emerg Med J. 2014;31(5):380-3. 